Studies in African Linguistics

Volume 32, Number 1, 2003

\title{
ON THE PROPERTIES OF EMAI'S KHI COPULA CONSTRUCTION ${ }^{*}$
}

\author{
Ronald P. Schaefer \& Francis O. Egbokhare \\ Southern Illinois University Edwardsville \& University of Ibadan
}

\begin{abstract}
This paper examines the equational identity (EI) construction in Nigeria's Edoid language Emai. It weighs this construction's grammatical properties against a complex of equational identity patterns developed in the crosslinguistic investigations of Stassen (1997). Although EI properties reveal its functional heritage, they fail to conform fully to Stassen's findings. While EI noun phrases are sensitive to information structure and definiteness values, the construction as a whole fails to exhibit crucial features. It evinces no third person limitation, manifests limited predicational structure, and demonstrates compatibility with a restricted range of temporal categories, although not indicative tense/aspect. It is the last of these that highlights the EI construction's obligatory subjunctive marking and its non-deictic temporal character.
\end{abstract}

* Data incorporated in this paper were collected as part of research support to the first author from the National Science Foundation (BNS \#9011338 and SBR \#9409552) and Southern Illinois University Edwardsville, as well as support to the second author from an Alexander Von Humboldt Fellowship at the Institut für Afrikanistik und Äthiopistik at Universität Hamburg. Its preparation derives from support provided by the College and University Affiliations Program (ASJY 1333) of the U.S. Department of State to Southern Illinois University Edwardsville and the University of Ibadan, Nigeria. We thank these institutions for their generous support, while not extending to them any responsibility for data interpretation. An carlier version of this paper was presented at the $30^{\text {th }}$ Annual Conference on African Linguistics held at the University of Illinois at Urbana-Champaign. We also thank editors and reviewers from Studies in African Linguistics for their constructive comments. 


\section{Introduction.}

As part of a crosslinguistic investigation of intransitive predication and its formal encoding, Stassen (1997) delineates the morphosyntactic properties of nominal predication. In contrast to adjectival and locational predication, its function is to specify class membership, i.e. assign the referent of the man to the class farmer in The man is a farmer. Stassen's wide-ranging database, including that from subSaharan Africa, reveals that nominal predication is frequently expressed through the morphosyntax of equational identity. The latter's primary function is to equate two referents previously assumed to be non-identical, e.g. It is the man whom we greeted that is a farmer or This man is the farmer whom we greeted. This concern with function leads Stassen to reach beyond the definiteness requirement of identity-construction noun phrases often noted in previous literature (Strawson 1974).

Stassen (1997) summarizes his crosslinguistic findings for identity constructions by highlighting four grammatical tendencies:

In sum, we can state that identity statements, on the basis of their semanticfunctional characteristics, can be predicted to exhibit the following structural features:

- their unmarked person form will be the third person;

- they will either lack tense-marking or have present tense;

- they will have zero predicate marking if the language allows this at all and

- they may feature topic/focus-marking devices in a more obligatory way than other sentence types do. (p. 110-111)

In other words, equational identity should be framed by construction elements whose grammatical origin lies in overtly signaling aspects of information structure. It should also prefer third person form (if person is marked); reject tense marking and associated temporal forms (or exclusively rely on present tense); and fail to evince predication (i.e. favor identification over predication and its consequent assignment of a subject argument to a predicate). These properties converge on so-called "zero copula" constructions (e.g. Russian's Moskova gorod 'Moscow is a city.'), which Stassen frequently finds encoding not only equational identity but also class membership. Nonetheless, not all languages allow a zero copula; some may instead dedicate a specific morphosyntactic construction to each of the functions equational identity and class membership. For such cases, closer scrutiny of Stassen's crosslinguistic tendencies may prove worthwhile. 
The West African language Emai (Edoid, Benue-Congo)' explicitly distinguishes the functions of equational identity from class membership in its morphosyntax. Equational identity is formally grounded to the BE form khi (ólí ómóhé nà lí $i$ khi ònwimè 'It is this man who is a farmer.') and class membership to the $\mathrm{BE}$ form vbi (óli ómóhé nà í ì vbì ònwìmè. 'This man is not a farmer.'). ${ }^{2}$ For this paper, we restrict analysis to the equational identity (EI) construction. Its character appears to reflect its functional heritage, although its grammatical properties do not follow entirely the specific crosslinguistic tendencies outlined by Stassen. EI noun phrases are sensitive to information structure and definiteness values but show no third person restriction. Emai's EI construction exhibits a limited but nonetheless evident predicational nature. And while EI constructions reject tense/aspect marking, they accept auxiliary and preverb categories with non-deictic temporal significance, thus casting doubt on a general atemporal characterization for equational identity.

\section{Overview of Equational Identity Construction.}

At the core of Emai's EI construction is the copula form khi, a focus position noun phrase preceding the copula and a post-copula noun phrase. ${ }^{3}$ The focus position noun phrase requires the positive focus (PF) marker $l i(\mathrm{la})$ or its negative focus (NF) counterpart $k i(1 \mathrm{~b})$. Either of these markers is immediately followed by an obligatory particle $i$ in subject position. The post-khi noun phrase exhibits no obligatory grammatical marking.

\footnotetext{
' The major subdivisions of the Edoid language family are outlined in Elugbe (1989). Emai is a member of the North-Central Branch. It is spoken by approximately 25-30,000 speakers across 12 villages in an area that is at longitude $6^{\circ}$ east of Greenwich Meridian and latitude $7^{\circ}$ north of the equator.

${ }^{2}$ Some of the typological character of Emai's five BE constructions is discussed in Schaefer and Egbokhare to appear.

${ }^{3}$ Orthographic conventions for Emai are consistent with those in Schaefer (1987) and Schaefer and Egbokhare (1999), where $<\underline{0}>$ represents a lax mid-back vowel, $<\underline{\mathbf{e}}>$ a lax mid-front vowel, and $\langle\mathrm{vb}>$ a voiced bilabial approximant. High tone is marked by an acute accent, low tone by a grave accent and high downstep by an acute accent followed by an apostrophe. Across an Emai clause, tone marking is grammatically conditioned by inflectional factors such as mood, tense/aspect, polarity as well as syntactic position. As a result, tone values on most lexical or grammatical items will appear to shift somewhat from construction to construction.
} 


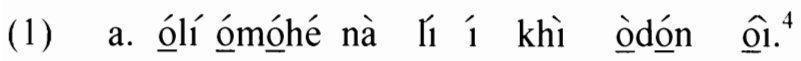
the man this PF ID COP husband her

'It is this man who is her husband.'

b. ólí ómóhé nà kí í khì òdón ộ1. the man this NF ID COP husband her 'It isn't this man who is her husband.'

The equational identity character of the khi construction is emphasized through obligatory number agreement. The noun phrase preceding the focus marker and the one following khi must agree in number, as indicated by the plural definite determiner élí and the plural demonstrative èần (2a), compared to the singular definite determiner ólí and the singular demonstrative òần (2c). Lack of number agreement between these positions leads to ungrammaticality ( $2 \mathrm{~b}$ and $2 \mathrm{~d}$ ).

a. éli úkpún lí óbín li 1 khì èân.

the cloth $\mathrm{R}$ dark PF ID COP those-ones

'It is the dark cloths that are those ones./Those ones are the dark cloths.'

b. *élí úkpún lí óbín lí ‘ 1 khì òân. the cloth $\mathrm{R}$ dark PF ID COP that-one

c. ólí úkpún ísì òjè lí the cloth ASS Oje PF ID COP that-one 'It is the cloth of Oje that is that one./ That one is the cloth of Oje.'

d. *ólí úkpún ísì òjè lí the cloth ASS Oje PF ID COP those-ones

\footnotetext{
${ }^{4}$ Abbreviations used throughout this study include the following: ABSI $=$ absolute intensification, $\mathrm{ADD}=$ additive, $\mathrm{ANT}=$ anterior, $\mathrm{ANTI}=$ anticipative, $\mathrm{APP}=$ applicative, $\mathrm{ASS}=$ associative, $\mathrm{C}=$ continuous, $\mathrm{CER}=$ certaintive, $\mathrm{CON}=$ conative, $\mathrm{CONC}=$ concessive, $\mathrm{COP}=$ copula, $\mathrm{CORC}=$ correlative conjunction, $\mathrm{DED}=$ deductive, $\mathrm{DMD}=$ distal manner deictic, $\mathrm{DUB}=$ dubitative, $\mathrm{DUR}=$ durative, $\mathrm{EG}=$ egressive, $\mathrm{H}=$ habitual, $\mathrm{HOR}=$ hortative, $\mathrm{HYP}=$ hypothetical, $\mathrm{IG}=$ ingressive, $\mathrm{NEG}=$ negative, $\mathrm{NF}=$ negative focus, $\mathrm{PA}=$ past absolute, $\mathrm{PCT}=$ punctual, $\mathrm{PF}=$ positive focus, $\mathrm{PR}=$ prohibitive, $\mathrm{PRED}=$ predictive, $\mathrm{R}=$ relator, $\mathrm{RC}=$ recurrent, REFL $=$ reflexive $\mathrm{REP}=$ repetitive, $\mathrm{SC}=$ subject concord, $\mathrm{SEQ}=$ sequential, $\mathrm{SUB}=$ subsequent, and TEMP $=$ temporal perspective.
} 
Emai's EI construction may have its origin in a grammatical device marking information structure, as Stassen's findings would suggest. The form khi with obligatory low tone combines with the subject particle $i$ to define right dislocation constructions and their "afterthought" function, as shown in (3).
a. ò gbé éwè, í khì òlí ómòhè.
he kill goat ID COP the man
'He killed a goat, that is, the man.'
b. éli 'imòhè gbé ộ̂,í khì èvé ísì òjè.
the men kill it ID COP goat ASS Oje
'The men killed it, that is, the goat of Oje.'

The form $k h i$ alone also designates a correlative conjunction, i.e. 'both NP and NP.' However, the resulting construction is limited to the discourse sensitive position topic. Preceding each correlatively conjoined noun phrase in topic position is the form khi with obligatory low tone.

(4) khì ò̀lı ómóhé khì ò̀ óvbékhán, yàn é émà. CORC the man CORC the youth they eat yam 'As for both the man and the youth, they ate yam.'

\section{Subject Position Constraints.}

Of the three positions associated with khi in EI constructions, subject is the most restricted. The position occupied by the subject particle $i$ requires an obligatory high tone. It fails to accept pronominal particles conveying person (third person singular $\underline{o} 5 \mathrm{a}$ or plural yán $5 \mathrm{~b}$ ), which are otherwise acceptable in subject position in focus constructions (yán 5c).
a. *óoll ómóhé nà li $\quad \underline{o}$ khì ònwìmè. 'It is this man who is a farmer.'
b. *éli ímóhé nà li yán khì inwìmè. the men these PF they COP farmers 'It is these men who are farmers.'




\section{c. él1 ímóhé nà li yán gbé ólí ófè. the men these PF they kill the rat 'It is these men who killed the rat.'}

Since the position occupied by the $i$ particle disallows subject particles expressing person, the $k h i$ construction reveals no person function and, thus, no evidence of a third person bias. Instead, the subject particle $i$ conveys an identiphoric function. ${ }^{5}$ It registers identification between construction noun phrases, i.e. the noun phrases in focus position and post-khi position. Two other Emai constructions marking identification relationships also require the particle $i$ in subject position. We have already seen its use in the right dislocation (afterthought) construction of (3), where the speaker registers subject (3a) or direct object (3b) identification explicitly in the phrase following khi. The $i$ particle is also obligatory in information questions of the 'which' type in (6), where it precedes the verb $y i$ 'declare, show, indicate' to query the identification of a referent.
1 yì ò̀li ómóhé li ó hían oól óràn?
ID indicate the man $\mathrm{R}$ he cut the wood
'Which one indicates the man who cut the wood?/
Which man cut the wood?'

Across equational identity, 'afterthought' and 'which' constructions, $i$ specifies a subject relation relative to a predicate, either $k h i$ or $y i$. Its status as grammatical subject is revealed by behavior with an auxiliary particle such as $m a$ 'surely, certainly.' In non-equational identity constructions, subject particles expressing person ( $\underline{o}$ /third person singular) precede a verb ( $d a$ 'drink') in constructions where an auxiliary is lacking (7a) but precede an auxiliary when one is present (má CER in $7 b$ ). A similar pattern characterizes subject particles in non-equational identity focus constructions ( $\underline{o}$ precedes $d a$ in $7 \mathrm{c}$ but $m a$ in $7 \mathrm{~d}$ ).

\footnotetext{
${ }^{5}$ The pronominal function identiphoric contrasts not only with definite personal pronouns (e.g. $\underline{o}$ 'he/she/it', yan 'they') but also with logophoric pronouns. The latter express referential identity between a human noun argument embedded in a clause under a verb of communication or cognition and the grammatical subject of that verb (e.g. yon in óli ómònhe ééní khì yọn gbé élí éwe. 'The man knew that he (himself) killed the goats.' Definite personal pronouns in embedded clauses show disjoint reference vis-à-vis the grammatical subject of the main clause verb (e.g. $\underline{o}$ in ólí ómiòhè ééni khì ò ghé élí éwè. 'The man knew that he (someone clsc) killed the goats.').
} 
(7)

a. ó dá ólí ényò.

he drink the wine

'He drank the wine.'

b. ó má dá ólı ényò.

he CER drink the wine

'He surely drank the wine.'

c. ôlí ómóhé nà lí ó dá óll ényò.

the man this PF he drink the wine

'It is this man who drank the wine.'

d. ólí ómóhé nà ll ó má dá óll ényò.

the man this PF he CER drink the wine

'It is this man who surely drank the wine.'

$k h i$ constructions as well as 'which' interrogatives with the same auxiliary require that the $i$ particle precede $m a(8 \mathrm{a}-\mathrm{b})$. $i$ thus registers a subject-predicate relation, and Emai's khi construction evinces predication, even of a limited sort, contra Stassen.

a. ólí ómóhé nà $\digamma_{1} \quad 1 \quad$ mà khí ódón ộ1.

the man this PF ID CER COP husband her

'It is this man who surely is her husband./

Her husband is surely this man.'

b. '1 mà ý́ óll ómóhé li ó hían ólí óràn?

ID CER indicate the man $R$ 3S cut the wood

'Which one surely indicates the man who cut the wood?/

Which man surely cut the wood?'

\section{Noun Phrase Constraints.}

The two noun phrase positions in Emai's EI construction exhibit a complex of symmetrical and asymmetrical structural constraints. The dimensions of these constraints fall along emphatic and definiteness lines rather than person. EI noun phrase positions are symmetrical in their rejection of overt non-definite marking by pronouns or post-nominal modifiers. They are asymmetrical in their acceptance of emphatic particles, the definite determiner and pronouns reflecting 
person.

Pre-khi focus position does not admit explicit indefinite marking. It admits proper names as well as proper names marked by the emphatic particle òkpá.

(9) òhí/ òhí òkpá lí ć1 khì òdón ộ1.

Ohi Ohi alone PF ID COP husband her

'It is Ohi / Ohi alone who is her husband.'

It accepts bare inanimate nouns with or without emphatic òkpá (10a) as well as inanimate nouns marked by the definite determiner ólí (10b), the latter also allowing emphatic òkpá. Overt definite marking is thus not obligatory in pre-khi position.

(10) a. èkpà / èkpà òkpá lí 1 l khì 'isì òjè.

bag bag alone PF ID COP ASS Oje

'It is a bag / a bag alone that is Oje's.'

b. ólì èkpà / óli èkpà òkpá lí 1 í khì ísì òjè.

the bag the bag alone PF ID COP ASS Oje

'It is the bag / the bag alone that is Oje's.'

Focus position allows emphatic pronouns regardless of person (11a), thus demonstrating no third person bias, as would be expected from Stassen's findings. Moreover, focus position admits no non-emphatic personal pronouns, as in (11b).

(11) a. mèmè / wèwwè / ìyōin lí 'í khì ònwìmè.

I you he PF ID COP farmer

'It is I/you/he who am/are/is a farmer.'

b. *ì / ù / $\underline{o}$ ll

I you he PF ID COP farmer

'It is $\mathrm{I} / \mathrm{you} / \mathrm{he}$ who am/are/is a farmer.'

Pre-khi focus position permits a wide range of impersonal pronouns, including numeral and universal quantifying pronouns, sortal ${ }^{6}$ pronouns and the demonstra-

"Sortal refers to a type of grammatical category in Emai specifying a "kind of" relation within a proximal/distal deictic frame. It occurs as pronoun or modifier, assuming the shapes $\underline{o} l l y \underline{o}$ 
tive pronouns in (12).

(12) óâin / ónà / ónộ li 'í khì àgbògbòràn.

that-one this-one next-one PF ID COP woodpecker

'It is that one /this one/ the next one that is a woodpecker.'

However, focus position fails to accept the existential quantifying pronoun óso 'some/certain one' whose referent is known to the speaker but not shared by speaker and hearer. Since ósò thus establishes a relation of specific reference, it is overtly non-definite.

$\begin{array}{llllll}\text { (13) *ósò } & \text { lí } & \text { 1 } & \text { khi } & \text { ísì èmé. } \\ \text { certain-one } & \text { PF } & \text { ID } & \text { COP } & \text { ASS } & \text { my }\end{array}$

'It is a certain one that is mine.'

Pre-khi focus position also allows pronominal-headed relative clauses (14a). They become unacceptable if marked by the recurrent (RC) particle $a$, whose generic, overtly non-definite character is signaled by translations with 'wh-ever' (14b).

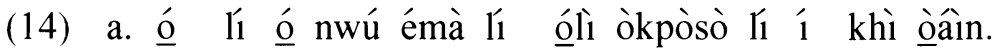

one $\mathrm{R}$ he give yam APP the woman PF ID COP that-one

'It is the one who gave yam to the woman who is that one. /

That one is the one who gave yam to the woman.'

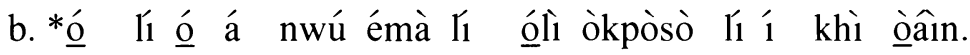

one R he RC give yam APP the woman PF ID COP that-one

'It is whoever gave yam to the woman that is that one. /

That one is whoever gave yam to the woman.'

With respect to post-nominal modifiers, focus position does not admit the existential quantifier ósò with its specific reference.

'that kind', ólıná 'this kind', éllyó 'those kinds', éniná 'these kinds' for the older generation familiar with Emai's oral tradition (Schaefer and Egbokhare 1999), but only élıyó 'that kind' for the younger generation. As a modifier in contemporary speech, it appears in phrases such as úkpún élyó 'cloth of that kind' and érá éllyó 'father of that kind' as well as a pronoun in expressions like élyyó lí $i$ khì àgbògbòràn. 'It is that kind of one that is a woodpecker. / A woodpecker is that kind of one.' 
$\begin{array}{llllllll}\text { *úkpún ósò lí } & \text { ó } & \text { khì ùkú èmé. } \\ \text { cloth } & \text { certain PF } & \text { ID } & \text { COP } & \text { inheritanace } & \text { ASS } & \text { èmy }\end{array}$

'It is a certain cloth that is my inheritance.'

The noun phrase position following khi is more constrained than its focus position counterpart. Post-khi position is sensitive to emphatic and definiteness but completely rejects person marking. Proper names occur in this position but not with emphatic òkpá.

(16) ódón ội lí

husband her PF ID COP Ololo Ololo alone

'It is her husband who is Ololo. / Ololo is the one who is her husband.'

Inanimate lexical nouns (è kpà 'bag') in post-khi position require the definite determiner ólí (17a); bare inanimate nouns are ungrammatical, as seen in (17b). Regardless of determiner presence, emphatic òkpá is disallowed in post-khi position, as shown in both (17a) and (17b). It thus appears that post-khi position must be overtly definite but can never be overtly emphatic.

a. 'ísi òjè li

ASS Oje PF ID COP the bag the bag alone

'The bag is Oje's. / The one that is Oje's is the bag.'

b. *'sì òjè ll ll $^{\prime}$ khì èkpà / èkpà òkpá.

ASS Oje PF ID COP bag bag alone

'A bag is Oje's. / The one that is Oje's is a bag.'

Post-khi position restricts pronominal forms. Regardless of pronoun person, it admits neither subject (18a), direct object (18b), nor emphatic personal forms (18c). It thus reflects no propensity for third person, contra Stassen, and no grammatical relation such as direct object.

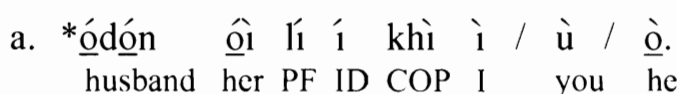

'Her husband is the one that is I/you/he.'

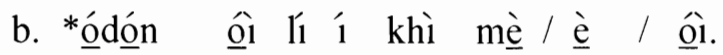
husband her PF ID COP me/ you/ him 


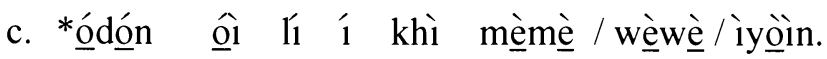

husband her PF ID COP I you he

'Her husband is the one that is I/you/he.'

Post-khi position permits various impersonal pronouns: demonstrative (éâin 'those ones,' ènốl 'next ones'), universal quantifying (èrèmé 'all'), and collective quantifying (èvèvá 'both').

(19) igbégbè ll ci khì èân / ènộ / èrèmé / èvèvá.

velvet PF ID COP those-ones next-ones all both

'It is the ones that are velvet that are those ones /the next ones / all / both./

Those ones / the next ones / all / both are the ones that are velvet.'

It fails, nonetheless, to accept the existential pronoun ósò 'some/certain one' and its specific reference requirement.

(20) *igbégbè lí $\quad 1 \quad$ khì ósò.

velvet PF ID COP certain-one

'It is velvet that a certain one is./ A certain one is the one that is velvet.'

And while post-khi position admits pronominally headed relative clauses (21a), such clauses are unacceptable if they incorporate the recurrent particle (RC) $a$ and its generic 'wh-ever' interpretation (21b).

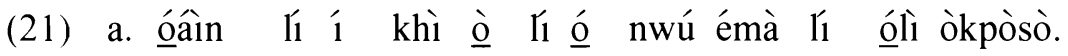
that-one PF ID COP one R he give yam APP the woman 'It is that one who is the one who gave yam to the woman.'

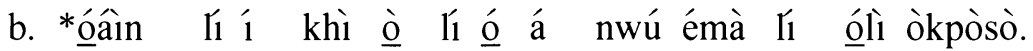
that-one PF ID COP one R he RC give yam APP the woman 'It is that one that is whoever gave yam to the woman.'

Relative to nominal modification, post-khi position does not allow the existential quantifier ósò 'certain, some' and its specific reference obligation.

(22) *àzén lí 1 k khì òmóhé ósò.

wizard PF ID COP man certain

'It is a wizard that is a certain man./

A certain man is the one who is a wizard.' 
The preceding has attempted to demonstrate that the two noun phrase positions in Emai's EI construction uniformly disallow overtly non-definite pronouns and modifiers. These positions also exhibit asymmetric distribution regarding emphatic and definiteness marking. Bare inanimate nouns and proper names with emphatic marking appear in pre-khi focus position, whereas post-khi position requires inanimate nouns marked as definite or proper names, although neither of these in post-khi position allows emphatic marking. Pre- $k h i$ focus position allows emphatic pronouns reflecting person, whereas post-khi position admits no personal pronouns at all. To this extent, neither noun phrase position associated with the $k h i$ construction reveals Stassen's postulated third person preference.

\section{Temporal Constraints.}

We direct attention now to the properties of $k h i$ in Emai's EI construction. As our point of departure, we take note of Stassen's (1997) review of the temporal character of identity constructions:

Thus, in their typical use, identity statements are the epitome of Time Stability. In fact, one might even doubt whether the concept of time is applicable to them at all; one might see them as essentially A-TEMPORAL or TIMELESS.... The timeless nature of identity statements may find its formal correlate in two different ways. First there are languages in which identity statements 'deny' the relevance of time specification by disallowing any formal tense marking at all. While other sentence types may (or must) be marked for tense, identity statements in these languages are constructed as 'a-temporal' or 'tenseless'.... Other languages, however, do not permit sentence types which lack formal tense-marking. In such a case, the language typically singles out one of the available tense forms as the preferred encoding for identity statements. [pp. 109110]

In contrast to the summary statements in Stassen, $k h i$ constructions do not reflect a completely atemporal character. This becomes evident through construction compatibility with auxiliaries and adverbial preverbs manifesting temporal significance.

Overall, khi constructions are incompatible with indicative mood. They reject tense/aspect marking in the imperfective and perfective, which in Emai reflects metrical tense values indicating degrees of remoteness from the deictic center (Haspelmath, König, Oesterreicher and Reuble 2001). Relative to the perfective, khi constructions do not show the completive past (compare 
ungrammatical $23 \mathrm{a}$ with its high tone khi preceded by high tone subject $i$ to grammatical $23 \mathrm{~b}$ with its high tone verb ghe 'kill' preceded by high tone subject ó) or completive present (compare ungrammatical $23 \mathrm{c}$ with its high tone khi preceded by low tone subject $i$ to grammatical $23 \mathrm{~d}$ with its high tone gbé preceded by low tone subject $\underline{\grave{o}}$ ).

(23) a. *oólí ómóhé nà lí 1 i khí ònwìmè.

the man this PF ID COP farmer

'It is this man who was a farmer.'

b. ó gbé ònwimè.

he kill farmer

'He killed a farmer.'

c. *oolí ómóhé nà lí ì khí ònwimè.

the man this PF ID COP farmer

'It is this man who has been a farmer.'

d. ò gbé ònwìmè.

he kill farmer

'He has killed a farmer.'

Likewise, $k h i$ fails to manifest imperfective tense/aspect. It does not permit the habitual, while a verb such as gbe 'beat' does (compare ungrammatical 24a with its high tone subject $i$, low tone habitual $\underline{o}$ and low tone khi to grammatical $24 \mathrm{~b}$ with its high tone subject $\underline{o}$, low tone habitual $\underline{o}$ and low tone verb ghè). khi also does not allow the continuous (compare ungrammatical $24 \mathrm{c}$ with its low tone subject $i$, high tone continuous $\underline{o}$ and low tone $k h i$ to grammatical $24 \mathrm{~d}$ with its low tone subject $\underline{o}$, high tone continuous $\underline{o}$ and low tone gbè). khi thus accepts neither the perfective nor imperfective tense/aspect of the indicative.

(24) a. *ólı ómóhé nà ll $l_{1}$ í ò khì ònwimè.

the man this PF ID $\mathrm{H}$ COP farmer

'It is this man who is (usually) a farmer.'

b. $\underline{o} \quad \underline{o}$ gbè inwìmè.

he $\mathrm{H}$ beat farmers

'He beats farmers.' 
c. *ólí ómóhé nà lí ì ó khì ònwimè. the man this PF ID $\mathrm{C}$ COP farmer

'It is this man who is being a farmer.'

d. $\underline{o}$ ó gbè ólì ònwìmè.

he $\mathrm{C}$ beat the farmer

'He is beating the farmer.'

In lieu of indicative marking, khi constructions evince properties consistent with Emai's subjunctive mood. ${ }^{7}$ The latter contrasts with the indicative in which the speaker commits himself to the true or false status of a proposition. The subjunctive's lack of commitment to truth value manifests itself in a restricted set of constructions that reflect, among others, imperative and embedded imperative constructions, as well as hortative (should'), conative ('went to'), anticipative ('about to'), and predictive ('will') significance. ${ }^{8}$ As with indicative, subjunctive mood in Emai is conveyed through tone marking. Its pattern is perhaps most easily seen in the effect of auxiliary and preverb elements on verb tone. When indicative constructions of perfective or imperfective tense/aspect are marked with a preverb or auxiliary (e.g. gbo/ ADD 'too'), verb tone is invariable relative to the unmarked construction. The verb $d a$ 'drink' has high tone in perfective $(25 \mathrm{a}-\mathrm{b})$ and low tone in imperfective $(25 \mathrm{c}-\mathrm{d})$, irrespective of gbo's presence.
a. óli ómóhé dá ényó éliyóo.
the man drink wine that-kind
'The man drank wine of that kind.'

${ }^{7}$ Following Lyons (1977), we take subjunctive as grounded to non-factivity conditions in which the speaker commits to neither the truth nor falsity of a proposition (Schaefer and Egbokhare 1998). We also note that lack of commitment to proposition truth value may occur for different reasons: either the proposition refers to an event which has yet to occur (the case with imperatives, anticipatives and others) or the proposition is assumed to be true within the societal universe (the apparent case with equational identity constructions).

${ }^{8}$ Subjunctive also includes prohibitive constructions like é è dá óli ényò. 'Don't drink the wine.', which place low tone on the prohibitive particle $\grave{e}$ as well as the immediately following auxiliary or preverb but not the verb, e.g. é è kè dá óli ényoò. 'Don't drink the wine anymore.' This has led us to distinguish strong (verb inclusive tone) and weak (verb non-inclusive tone) subjunctive patterns for Emai (Schaefer and Egbokhare 1998). 
b. óll ómóhé gbó dá ényó éliyó.

the man ADD drink wine that-kind

'The man drank wine of that kind too.'

c. ólí ómóhé ó ò dà ènyó éliyó.

the man $\mathrm{SC} \mathrm{H}$ drink wine that-kind

'The man drinks wine of that kind.'

d. ólil ómóhé ó ò gbó dà ènyó éliyó.

the man SC H ADD drink wine that-kind

'The man drinks wine of that kind too.'

When subjunctive constructions include a preverb or auxiliary, verb tone is variable. The verb $d a$ has low tone in the unmarked construction (26a) but high tone in the presence of $g b o(26 b)$.

a. ól1 ómóhé ló dà òlı́ ényọ.

the man PRED drink the winc

'The man will drink the wine.'

b. ólı ómóhé ló gbò dá vbí ólí ényó. the man PRED ADD drink LOC the wine

'The man will drink from the wine too.'

What then is khi's tonal pattern? Consistent with the subjunctive in (26), khi manifests low tone in a structure unmarked by an auxiliary or preverb (27a) but high tone when a preverb like gbo is present (27b).

a. òhí kí 'i khì óbá?

Ohi NF ID COP Oba/king

'Isn't it Ohi who is Oba?'

b. òhí kí 'i gbò khí óbá'?

Ohi NF ID ADD COP Oba/king

'Isn't it Ohi who is Oba too?'

Relative to post-verbal adverbs and particles linked to tense/aspect marking, $k h i$ is extremely constrained. It fails to co-occur with the post-verbal temporal perspective particle lee (28a), which makes reference to event onset or endpoint 
depending on tense/aspect. With verbs like $e$ 'eat,' lee has an 'already finished' interpretation in perfective (28b) and an 'already starting to' interpretation in imperfective (28c).

(28) a. *ólí ómóhé nà l1 1 i khì ònwìmè léé.

the man this PF ID COP farmer TEMP

'It is this man who is already a farmer.'

b. ôlı ómóhé nà é oól émà léé.

the man this eat the yam TEMP

'This man has already finished eating the yam. /

This man has finished eating the yam.'

c. ólı́ ómóhé nà ò̀ ó è ò̀lı émá lèé.

the man this $\mathrm{SC} \mathrm{C}$ eat the yam TEMP

'This man is already starting to eat the yam. /

This man is already eating the yam.'

As well, $k h i$ constructions reject the full range of post-verbal temporal adverbs linked to the deictic moment of utterance or the deictic center of discourse. Excluded are adverbs in (29) such as éènà 'today,' ènyáà 'just now,' èghéênà 'recently,' òdẹ 'yesterday, élá úkpè 'last year,' and úkpùukpè 'yearly.'

(29) a. *oóli ómóhé nà lla 11 khì ònwímé éènà / ènyáà. the man this PF ID COP farmer today just-now 'It is this man who is a farmer today / just now.'

b. *oólí ómóhé nà lí 1 i khì ònwímé ègheeènà / òdè. the man this PF ID COP farmer recently yesterday 'It is this man who was a farmer recently / yesterday.'

c. *oólí ómóhé nà lí 1 i khì ònwímé élá úkpè. the man this PF ID COP farmer last year 'It is this man who was a farmer last year.'

d. *óolí ómóhé nà lí 1 i khì ònwímé úkpùúkpè. the man this PF ID COP farmer every-year 'It is this man who is a farmer every year.' 
These adverbs are otherwise compatible with verbs like $e$ 'eat' marked for tense/aspect (Schaefer and Egbokhare 1997), for example ènyáa 'just now' in the continuous (30a), èghéènà 'recently' in the completive present (30b) and élá úkpè 'last year' in the completive past (30c).

(30) a. ólı́ ómòhè ò ó è òlı émá ènyáà.

the man SC $\mathrm{C}$ eat the yam just-now

'The man is eating the yam just now.'

b. óli ómòhè é ólí émá èghéènà.

the man eat the yam recently

'The man has eaten the yam recently.'

c. ốlı ómóhé é oól1 émá êlá úkpè.

the man eat the yam last year

'The man ate the yam last year.'

$k h i$ 's rejection of tense/aspect extends to its failure to accept predicate negation. While verbs like gbe 'kill' allow predicate negation ( $i$ / NEG 31a), khi does not (31b).

(31) a. ólı ómóhé nà 'i ì gbè ólì ònwìmè.

the man this SC NEG kill the farmer

'This man did not kill the farmer.'



the man this PF ID NEG COP farmer

'It is this man who is not a farmer.'

Tense/aspect properties aside, $k h i$ constructions allow only selected auxiliaries and preverbs, some of which manifest a temporal nature. First we note that $k h i$ is incompatible with all event (deontic and dynamic) modality particles (Palmer 2001 ), those that convey obligation, ability or willingness. Khi does not permit predictive ló /PRED (32a), anticipative ló /ANTI or hortative $i$ /HOR (32b)

\footnotetext{
${ }^{9}$ Although one might be tempted to view the $i / \mathrm{SC}$ in negative constructions as another instance of the identiphoric pronoun $i / \mathrm{ID}$, negative constructions with pronominal subjects show person distinctions, as in ó i gbè ốl ônwìmèe. 'He did not kill the farmer.' and yán ì gbè ól óonwimèe. 'They did not kill the farmer.' $i /$ ID never alternates with a personal pronoun.
} 
particles. At least two of these (predictive and anticipative) incorporate a metrical tense dimension, reflecting proximal/distal temporal degrees relative to the moment of utterance or some other stipulated reference time (Schaefer and Egbokhare 1997).

(32) a. *oóli ómóhé nà li li ló khì ònwìmè. the man this PF ID PRED COP farmer

'It is this man who will be a farmer.'

b. *oólı ómóhé nà lí ì ló / 1 l khi ònwimè. the man this PF ID ANTI/ HOR COP farmer 'It is this man who is about to be/ should be a farmer.'

Khi also restricts particles of epistemic modality (Palmer 2001), the latter referencing speaker judgments of degree of certainty in a proposition's truth value. $k h i$ constructions admit certaintive ma /CER (33a), concessive rere /CONC (33b), and dubitative $v b a / D U B(33 c)$, although the latter two require a yes/no question. $K h i$ does not allow the particles hypothetical $k h a / H Y P$ or deductive $z a / D E D(33 \mathrm{~d})$, which specify a speaker's modal judgment based entirely on logical deduction or inference.

(33) a. òhí li 'i mà khí óbá'.

Ohi PF ID CER COP Oba

'It is Ohi who surely is the Oba.'

b. òhí lí 'i rèrè khí óbá'?

Ohi PF ID CONC COP Oba

'So is it Ohi who is even the Oba?'

c. òhí lí ‘́ vbà khí óbá?

Ohi PF ID DUB COP Oba

'Could it be that it is really Ohi who is the Oba?'

d. *òní li 'i khà / zà khí óbá'.

Ohi PF ID HYP DED COP Oba

'It is Ohi who would have been/ must have been the Oba.'

$K h i$ is compatible with Emai's relative tense auxiliaries. These are particles that relate situation time to contextually given reference time rather than to time of 
utterance (Haspelmath, König, Oesterreicher and Reuble 2001). We find that khi accepts two relative tense particles. It allows anterior ke /ANT (with dependent clause sense 'after' and main clause sense 'since then, anymore' 34a) and

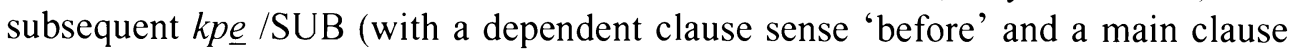
sense 'yet' 34b). Khi never occurs with relative tense re /SEQ (34c), whose 'and then' sequential meaning is restricted to main clauses.

(34) a. èkpèn lí í kè khí ójé ísì éànmì.

leopard PF ID ANT COP king ASS animal

'It is the leopard who has been king of the animals since then.'

b. èkpè̀n lí $l_{1}^{1}$ kpè khí ójé ísì éànmì.

leopard PF ID SUB COP king ASS animal

'It is the leopard who is yet king of the animals.'

c. *è̀kpèn lí $l_{1}^{1}$ rè khí ójé ísì éànmì.

leopard PF ID SEQ COP king ASS animal

'It is the leopard who (and) then was king of the animals.'

As for preverb classes, $k h i$ combines with member items in a manner reflecting at least in part their event-directed or participant-directed nature (Schaefer and Egbokhare 2000). The latter distinction refers to alternative domains over which preverb meaning has influence: either the event encoded by the predicate or an event participant designated by grammatical subject or direct object. Some eventdirected particles with temporal significance are grammatical with khi, whereas none of the participant-directed particles are. From the event-directed evaluative class, only kuku's 'after all' assessment of information is grammatical in khi constructions (35a-b).

(35) a. òhí lí 1 i kùkù khí óbá'.

Ohi PF ID after-all COP Oba

'It is Ohi afterall who is the Oba.'

b. *òhí lí í dùù / wòò khí óbá'.

Ohi PF ID in-fact instead COP Oba

'It is Ohi in fact / instead who is the Oba.'

Among event-directed temporal preverbs, kpao 'initially' is acceptable (36a), although the more deictic orientation of bobo 'promptly' is not (36b). 
(36) a. èkpèn lí 1 kpàò khí ójé ísì éànmì. leopard PF ID initially COP king ASS animal 'It is the leopard who was initially king of the animals.'

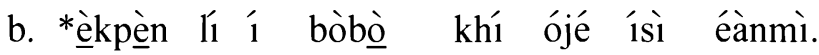
leopard PF ID promptly COP king ASS animal 'It is the leopard who promptly was king of the animals.'

Khi's occurrence is relatively constrained with aspectualizer preverbs, a class of grammatical forms semantically akin to aspectualizer verbs (e.g. 'start,' 'stop,' and 'continue') in other languages (Haspelmath, König, Oesterreicher and Reuble $2001){ }^{10}$ Emai aspectualizer preverbs reference temporal phases of an event (ingressive, egressive) or construe an entire event as a temporal phase within a larger stretch of time (repetitive, additive, conative, punctual, and durative). Khi constructions admit two event-directed aspectualizer preverbs, both conditioned by negative focus with $k i$ and interrogative force. Each has a temporal character, additive $g b o$ 'too/also' (37a) and durative se 'continue on' (37b).
a. òhí kí 'i gbò khí óbá’?
Ohi NF ID ADD COP Oba
'Isn't it Ohi who is also Oba?'

b. òhí ḱ1 'i sè khí óbá'?

Ohi NF ID DUR COP Oba

'Isn't it Ohi who continues to be Oba?'

No other aspectualizers, among them repetitive che /REP and punctual ghe /PCT (38a), conative $\underline{o O} / \mathrm{CON}$ (38b), ingressive $y a / \mathrm{IG}$, egressive $m \underline{o} / \mathrm{EG}$ (38c), and past absolutes ya /PA and $m \underline{Q} / \mathrm{PA}(38 \mathrm{~d})$, are grammatical with $k h i$, irrespective of speech act force or focus particle polarity.

\footnotetext{
${ }^{10}$ Emai has few aspectualizer verbs of the general type conveyed by 'to start', 'to continue' or 'to stop.' And Emai aspectualizer particles differ from auxiliaries in their propensity to occur in imperative constructions and to occupy positions following auxiliaries and preceding other preverbal adverbs.
} 
a. *ò'í ḱ1 'i chè / ghè khí óbá?

Ohi NF ID REP PCT COP Oba

'Isn't it Ohi who is again/just Oba?'

b. *òhí kí 'i óó khì óbá?

Ohi NF ID CON COP Oba

'Isn't it Ohi who went to be Oba?'

c. *òhí ḱ1 ì yà / mò khí óbá'.

Ohi NF ID IG EG COP Oba

'It is Ohi who was almost Oba.'

d. *òhí kí í yà / mò khí óbá'.

Ohi NF ID PA PA COP Oba

'It is Ohi who was formerly/at one time Oba.'

None of the remaining preverb classes is grammatical in khi constructions. The event-directed preverb class incorporating manner deictics like 'iyó 'that way' is ungrammatical. Equally rejected are participant-directed preverb classes typified by subject attributive dabo 'deliberately,' absolute intensifier zemi /ABSI, and emphatic subject reflexive dòbó/REFL.

*òhí li cí iyó / dàbò / zèmì / dòbóô ồ khí óbá'.

Ohi PF ID DMD deliberately ABSI REFL him COP Oba

'It is Ohi who that way/deliberately/really/himself is Oba.'

\section{Discussion}

As we have observed, Emai's khi construction manifests some of the temporal and predicational nature Stassen's crosslinguistic findings deny identity constructions. The grammatical situation in Emai appears more complex than predicted. However, it does not involve a simple rejection of the pattern outlined by Stassen.

Since $k h i$ must be preceded by the subject particle $i$, EI constructions evinced a predicational nature, albeit limited, distinguishing subject from predicate. And although EI constructions failed to accept subject or direct object personal pronouns, no third person preference was evident. Focus position accepted first, second and third person emphatic pronoun forms, while post-khi position failed to accept any personal pronouns, relying exclusively on 
impersonal forms.

In addition, the two principal noun phrases linked by the khi copula revealed a number of asymmetric information-level properties, especially with regard to definite and emphatic marking. Focus position accepted bare inanimate nouns as well as proper names and inanimate nouns with emphatic marking, while post-khi position accepted neither bare inanimate nouns nor emphatically marked proper names or inanimate nouns. Only post-khi position required nominals marked as definite. Moreover, both positions equally rejected nominals overtly marked as non-definite.

As for temporal character, EI constructions failed to exhibit tonal patterns or particles associated with Emai's tense/aspect types, imperfective and perfective. Linked to this restriction is khi's failure to admit post-verbal temporal adverbs like òde 'yesterday' and the temporal perspective particle lee 'already.' EI constructions, instead, manifested the subjunctive: variable verb tone correlating with the presence or absence of an auxiliary or preverb. Since EI constructions also accepted a range of auxiliary and preverb particles with temporal character, one cannot claim along with Stassen (1997) that identity constructions are completely atemporal. Khi allowed the relative tense particles ke 'since then' and kpe 'yet,' the aspectualizer particles gbo 'too/also' and se 'continue on,' and the preverb kpao 'initially.' While these particles may not be linked to tense, they are not atemporal. Rather than relate an event to the deictic moment of utterance, they relate one event to another in discourse without obligatory reference to the moment of utterance. They establish a non-deictic temporal character for EI constructions that allows the latter to be located in discourse. The Emai data suggest that it would be preferable to construe EI constructions as non-deictic rather than atemporal.

The preceding interpretation of Emai's EI construction reveals its essential compatibility with the subjunctive mood. It may prove worthwhile to investigate the grammatical encoding of EI constructions more carefully in other African languages, in particular their possible acceptance or rejection of forms related to tense/aspect. This might allow us to determine whether the patterns uncovered in this study are peculiar to Emai, and perhaps the Edoid family, or whether they reflect broader tendencies in Benue-Congo or Africa. Secondly, it would seem useful to scrutinize the grammatical encoding of equational identity constructions for temporal marking. Which categories with temporal significance are permissible in equational identity constructions? To what extent are particular temporal categories compatible with the indicative or subjunctive mood marking of equational identity? At the very least, this brief excursion into Emai's EI constructions sug- 
gests that the formal expression of temporality, predication and person in equational identity constructions in Africa would benefit from closer scrutiny.

\section{REFERENCES}

Elugbe, Ben. 1989. Comparative Edoid: Phonology and Lexicon. Port Harcourt: University of Port Harcourt Press.

Haspelmath, Martin, Ekkehard König, Wulf Oesterreicher and Wolfgang Reuble. eds. 2001. Language Typology and Language Universals: An International Handbook. Berlin: Mouton de Gruyter.

Lyons, John. 1977. Semantics, Volume I and II. Cambridge: Cambridge University Press.

Palmer, F. R. 2001. Mood and Modality. New York: Cambridge University Press. [Second Edition; First Edition 1986.]

Schaefer, Ronald P.1987. An Initial Orthography and Lexicon for Emai: an Edoid Language of Nigeria. Bloomington: Indiana University Linguistics Club.

Schaefer, Ronald P. and Francis O. Egbokhare. 1997. "Emai's temporal adverbs". Language History and Linguistic Description in Africa, ed. by Ian Maddieson and Tom Hinnebush. Lawrenceville, NJ: African World Press. Pp. 269-276

Schaefer, Ronald P. and Francis O. Egbokhare. 1998. "On tone and mood correlations in Emai". Research in African Languages and Linguistics 4.1.1-13.

Schaefer, Ronald P. and Francis O. Egbokhare. eds. 1999. Oral Tradition Narratives of the Emai People, Part I and Part II. Hamburg: LIT Verlag.

Schaefer, Ronald P. and Francis O. Egbokhare. 2000. "Emai preverb order". Proceedings from the $2^{\text {nd }}$ World Congress of African Linguistics, Leipzig 1997, ed. 
by Ekkehard Wolff and Orin Gensler. Köln: Rüdiger Köppe Verlag. Pp. 733746.

Schaefer, Ronald P. and Francis O. Egbokhare. In preparation. An Emai-English Dictionary. Mouton Trends in Linguistic Documentation. Berlin: Mouton de Gruyter.

Schaefer, Ronald P. and Francis O. Egbokhare. In press. "Toward a typological perspective for Emai's BE Constructions". Studies in African Linguistic Typology, ed. by F.K. Erhard Voeltz. Philadelphia: John Benjamins.

Stassen, Leon. 1997. Intransitive Predication. Oxford: Clarendon Press.

Strawson, P.F. 1974. Subject and Predicate in Logic and Grammar. London: Methuen.

Department of English Language and Linguistics

Southern Illinois University

Edwardsville, IL 62026-1431

rschaef@siue.edu

Department of Linguistics

University of Ibadan

Ibadan, Nigeria

foegbokhare@yahoo.com
Received October 30, 2003 accepted January 5, 2004 